\title{
Lactobacillus sucicola sp. nov., a motile lactic acid bacterium isolated from oak tree (Quercus sp.) sap
}

\author{
Tomohiro Irisawa and Sanae Okada
}

Correspondence

Tomohiro Irisawa

sawa37@hotmail.com

\author{
Department of Environmental Symbiotic Studies, Tokyo University of Agriculture, Tokyo 156-8502, \\ Japan
}

\begin{abstract}
Three strains of rod-shaped and motile lactic acid bacteria, NRIC $0736^{\top}$, NRIC 0735 and NRIC 0737 were isolated from sap obtained from two different oak trees (Quercus sp.) on Awashima Island, Kagawa Prefecture, Japan. The three strains showed nearly identical 16S rRNA gene sequences ( $>99.7 \%$ sequence similarity). The novel strains showed low $16 \mathrm{~S}$ rRNA gene sequence similarities to recognized species of lactic acid bacteria. High gene sequence similarities were found between strain NRIC $0736^{\top}$ and Lactobacillus satsumensis NRIC $0604^{\top}$ (96.3\%), Lactobacillus mali DSM $20444^{\top}$ (95.3\%) and Lactobacillus vini DSM $20605^{\top}$ (95.3\%). DNA-DNA relatedness values revealed the genotypic separation of the three novel isolates from these recognized species. It is concluded that the three new isolates represent a novel species, for which the name Lactobacillus sucicola sp. nov. is proposed. The type strain is NRIC $0736^{\top}\left(=J C M 15457^{\top}=\right.$ DSM $\left.21376^{\top}\right)$.
\end{abstract}

During a study of the diversity of lactic acid bacteria (LAB) on plant material, 31 strains were isolated from sap obtained from two different oak trees (Quercus sp.), A and B, from Awashima Island, Kagawa Prefecture, Japan, in July 2006. Beetles, hornets and other insects are known to suck the sap from these trees. After $16 \mathrm{~S}$ rRNA gene sequence analysis of all the isolates, three strains, NRIC $0736^{\mathrm{T}}$ and NRIC 0735 (from tree A) and NRIC 0737 (from tree B) were chosen for subsequent study because they showed low 16S rRNA gene sequence similarities with known LAB species (<97\%). Moreover, levels of DNADNA relatedness also separated the novel strains from known LAB. Based on the results of phenotypic and genotypic analyses in this study, the three new strains were found to represent a novel species of LAB.

The enrichment culture approach was employed to isolate LAB from the oak tree sap. MRS broth (Oxoid) was used as the isolation medium. This broth contained inhibitors, 10 p.p.m. sodium azide and 10 p.p.m. cycloheximide, to inhibit the growth of aerobic bacteria and fungi. The oak tree sap was added to MRS broth and incubated at $30{ }^{\circ} \mathrm{C}$. After incubation for 3-4 days, the broth was plated out on MRS agar (Oxoid) containing $0.5 \% \mathrm{CaCO}_{3}$ and the previously mentioned inhibitors. The plates were incubated

Abbreviation: $L A B$, lactic acid bacteria.

The GenBank/EMBL/DDBJ accession numbers for the 16S rRNA gene sequences of strains NRIC 0735, NRIC 0736 ${ }^{\top}$ and NRIC 0737 are AB458681, AB433982 and AB458682, respectively.

A micrograph of a cell of Lactobacillus sucicola NRIC $0736^{\top}$ grown on an MRS slant at $30{ }^{\circ} \mathrm{C}$ for $15 \mathrm{~h}$ showing peritrichous flagella is available with the online version of this paper. at $30{ }^{\circ} \mathrm{C}$. Colonies with a clear zone, identified as acidproducing bacteria, were randomly selected from the plates. These were then maintained on MRS agar containing $\mathrm{CaCO}_{3}$.

Chromosomal DNA was prepared from the novel strains using the method of Zhu et al. (1993). The DNA was then used as a template for $16 \mathrm{~S}$ rRNA gene sequence amplification. The amplification was performed using two primers: $8 \mathrm{~F}$ (5'-AGAGTTTGATCMTGGCTCAG-3', positions 8-27) and 15R (5'-AAGGAGGTGATCCARCCGCA-3', positions 1541-1522). The position numbers were based on the Escherichia coli numbering system (GenBank accession no. V00348; Brosius et al., 1981). The PCR products were purified using the Wizard SV Gel and PCR Clean-Up System (Promega). The products were sequenced using a Big Dye Terminator v.1.1 cycle sequencing kit (Applied Biosystems) and an automatic DNA sequencer (model 310 Genetic Analyzer; ABI PRISM). The seven oligonucleotides 8F, 930F (5'-GCACAAGCGGTGGAGCATGTGG-3', positions 933-954), 1400F (5'-TGTACACACCGCCCGT-3', positions 13911406), 520R (5'-ACCGCGGCTGCTGGC- $3^{\prime}$, positions 531-517), 800R (5'-CAGGACTACCAGGGTATCTAAT-3', positions 804-787), 1100R (5'-AGGGTTGCGCTCGTTG-3', positions 1115-1100) and 15R were used as primers for sequencing $16 \mathrm{~S}$ rRNA gene fragments. The closest recognized relatives of the novel isolates were determined by searching 16S rRNA gene sequences obtained from the EMBL/GenBank/DDBJ databases. These sequences were aligned using CLUSTAL_X (version 1.18) (Thompson et al., 1997). A distance matrix was obtained by the two-parameter method of Kimura (1980). The neighbour-joining method 
was used to construct a phylogenetic tree (Saitou \& Nei, 1987). The robustness of the individual branches of the tree was established by bootstrapping with 1000 replicates (Felsenstein, 1985).

The 16S rRNA gene sequences (position 8-1541) of strains NRIC $0736^{\mathrm{T}}$, NRIC 0735 and NRIC 0737 were determined and compared with each other. Strain NRIC $0736^{\mathrm{T}}$ showed $99.7 \%$ and $99.7 \%$ gene sequence similarities with strains NRIC 0735 and NRIC 0737, respectively. The sequence of strain NRIC $0736^{\mathrm{T}}$ was compared with those of recognized species. Strain NRIC $0736^{\mathrm{T}}$ showed high gene sequence similarities to Lactobacillus satsumensis NRIC $0644^{\mathrm{T}}$ (96.6\%), Lactobacillus mali DSM $20444^{\mathrm{T}}(95.3 \%)$ and Lactobacillus vini DSM $20605^{\mathrm{T}}(95.3 \%)$. It was therefore concluded that the three novel isolates belonged to the same taxon and were located in the Lactobacillus caseiPediococcus group (Fig. 1) (Collins et al., 1991).

Extraction and isolation of bacterial DNA was performed according to the method of Marmur (1961) as modified by Ezaki et al. (1983). DNA-DNA hybridization was carried out with the fluorometric hybridization technique in microdilution wells with labelling of DNA with photobiotin (Ezaki et al., 1989). The DNA G + C contents of the strains were determined by HPLC as described by Tamaoka \& Komagata (1984).

Strains NRIC $0736^{\mathrm{T}}$, NRIC 0735 and NRIC 0737 showed high levels of DNA-DNA relatedness (88-100\%) with one another. Therefore, it was concluded that the new isolates belong to the same taxon. In contrast, strain NRIC $0736^{\mathrm{T}}$ showed low levels of DNA-DNA relatedness to the type strains of L. satsumensis (11\%) and L. mali (11\%). The
DNA G $+\mathrm{C}$ contents of the three novel strains ranged from 37 to $38 \mathrm{~mol} \%$ (Table 1 ).

Cell morphology and Gram staining (Hucker \& Conn, 1923) were examined using cells grown in GYP broth at $30{ }^{\circ} \mathrm{C}$ for $24 \mathrm{~h}$. GYP broth comprised $\left(1^{-1}\right.$ distilled water): $10 \mathrm{~g}$ D-glucose, $10 \mathrm{~g}$ yeast extract, $5.0 \mathrm{~g}$ peptone, $2.0 \mathrm{~g}$ $\mathrm{C}_{2} \mathrm{H}_{3} \mathrm{O}_{2} \mathrm{Na} .3 \mathrm{H}_{2} \mathrm{O}, 0.5 \mathrm{~g}$ Tween $80,200 \mathrm{mg} \mathrm{MgSO}{ }_{4} \cdot 7 \mathrm{H}_{2} \mathrm{O}$, $10 \mathrm{mg} \mathrm{MnSO}_{4} \cdot 4 \mathrm{H}_{2} \mathrm{O}, 10 \mathrm{mg} \mathrm{FeSO}_{4} \cdot 7 \mathrm{H}_{2} \mathrm{O}$ and $10 \mathrm{mg}$ $\mathrm{NaCl} ; \mathrm{pH}$ was adjusted to $\mathrm{pH} 6.8$ with $\mathrm{NaOH}$. Motility was tested in GYP soft agar and flagella were stained by the method of Toda (1928). Catalase activity was determined by the addition of $3 \%(\mathrm{w} / \mathrm{v}) \mathrm{H}_{2} \mathrm{O}_{2}$ to the fresh cells grown on GYP agar. Gas production from glucose was determined using a Durham tube in GYP broth. The type of fermentation was determined using an F-kit ethanol (Roche Diagnostic) as described by Okada et al. (1991). The isomer of lactic acid was determined by HPLC as described by Manome et al. (1998). Acid formation from carbohydrates was assessed by the use of a basal medium of GYP broth with glucose omitted. The acid produced in $2 \mathrm{ml}$ broth was titrated with $0.1 \mathrm{M} \mathrm{NaOH}$. The effect of temperature $\left(10,15,30,37,45\right.$ and $\left.50{ }^{\circ} \mathrm{C}\right)$ on growth was tested by using GYP broth. Tolerance to $\mathrm{NaCl}$ was examined in GYP containing $5 \%(w / v) ~ \mathrm{NaCl}$ after incubation for 5 days at $30{ }^{\circ} \mathrm{C}$. The preparation of cell walls and the determination of peptidoglycan types were carried out according to Komagata \& Suzuki (1987).

Production of dextran from sucrose was investigated by culturing on SYP plates. SYP medium comprised $\left(1^{-1}\right.$ distilled water): $20 \mathrm{~g}$ sucrose, $10 \mathrm{~g}$ yeast extract, $10 \mathrm{~g}$ peptone, $5.0 \mathrm{~g} \mathrm{C}_{2} \mathrm{H}_{3} \mathrm{O}_{2} \mathrm{Na} .3 \mathrm{H}_{2} \mathrm{O}, 0.5 \mathrm{~g}$ Tween $80,200 \mathrm{mg}$

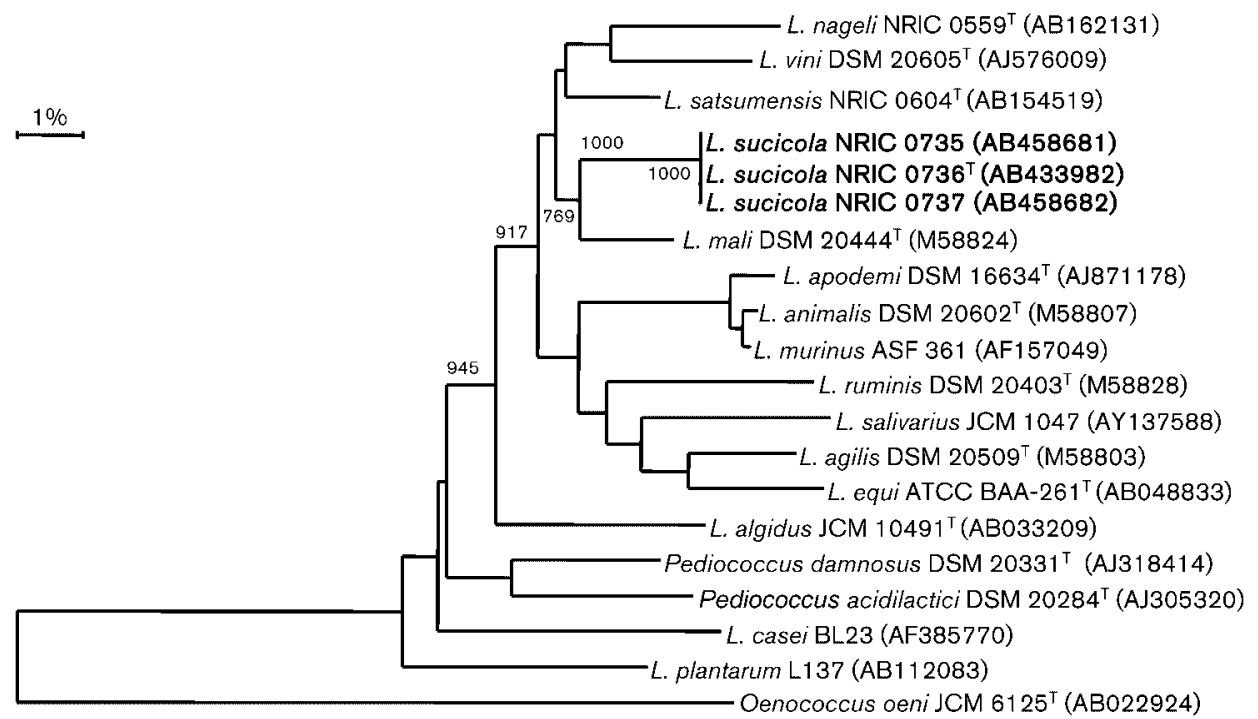

Fig. 1. Phylogenetic relationships of Lactobacillus sucicola NRIC $0736^{\top}$ and species in the Lactobacillus casei-Pediococcus group based on 16S rRNA gene sequences. The tree was constructed by the neighbour-joining method and approximately $1400 \mathrm{nt}$ were used for comparison. Oenococcus oeni JCM $6125^{\top}$ was used as an outgroup. Bar, $1 \%$ sequence divergence. 
Table 1. DNA G+C contents and DNA-DNA relatedness between Lactobacillus sucicola sp. nov. and phylogenetically closely related species of the genus Lactobacillus

\begin{tabular}{|lcccc|}
\hline Strain & DNA G+C content (mol\%) & \multicolumn{3}{c|}{ Hybridization (\%) with DNA from: } \\
\cline { 3 - 5 } & & $\mathbf{1}$ & $\mathbf{2}$ & $\mathbf{3}$ \\
\hline 1. Lactobacillus sucicola NRIC 0735 & 37 & $(100)$ & & $\mathbf{5}$ \\
2. Lactobacillus sucicola NRIC $0736^{\mathrm{T}}$ & 38 & 89 & $(100)$ & $(100)$ \\
3. Lactobacillus sucicola NRIC 0737 & 38 & 88 & 100 & 11 \\
4. Lactobacillus satsumensis NRIC $0644^{\mathrm{T}}$ & 40 & 8 & 11 & $(100)$ \\
5. Lactobacillus mali NRIC $1692^{\mathrm{T}}$ & 33 & 9 & 11 & 11 \\
\end{tabular}

$\mathrm{MgSO}_{4} \cdot 7 \mathrm{H}_{2} \mathrm{O}, 10 \mathrm{mg} \mathrm{MnSO}{ }_{4} \cdot 4 \mathrm{H}_{2} \mathrm{O}, 10 \mathrm{mg} \mathrm{FeSO}{ }_{4} \cdot 7 \mathrm{H}_{2} \mathrm{O}$, $10 \mathrm{mg} \mathrm{NaCl}$ and $12 \mathrm{~g}$ agar; the $\mathrm{pH}$ was adjusted to $\mathrm{pH} 6.8$ with $\mathrm{NaOH}$. The three novel strains were cultured on SYP agar plates at $30{ }^{\circ} \mathrm{C}$. After 3 days incubation, all of the novel strains produced a viscid substance around the colonies. The viscid substance was scraped from the plate and was suspended in $0.5 \mathrm{ml}$ water in a $2.0 \mathrm{ml}$ microtube. After the addition of $1.0 \mathrm{ml} 99 \%$ ethanol, the microtubes were kept at $4{ }^{\circ} \mathrm{C}$ for $30 \mathrm{~min}$. The suspension was then centrifuged at $6000 \mathrm{~g}$ for $3 \mathrm{~min}$, the supernatant was removed and the precipitate was dried. Approximately $1 \mathrm{mg}$ dried material was hydrolysed with $1.0 \mathrm{ml} 6 \mathrm{M} \mathrm{HCl}$ in a vacuum hydrolysis tube at $100{ }^{\circ} \mathrm{C}$ for $6 \mathrm{~h}$. After cooling, the hydrolysate was concentrated to dryness using a rotary evaporator. The dried material was dissolved in $30 \mu$ l water and a $3 \mu \mathrm{l}$ sample was then applied on the base line of a cellulose TLC plate (Merck). The TLC plate was developed with a solvent system of iso-propanol/pyridine/acetic acid/water $(8: 8: 1: 4, \mathrm{v} / \mathrm{v})$. Development took approximately $3 \mathrm{~h}$ or more. Spots were visualized with $\mathrm{AgNO}_{3}$ reagent. One spot appeared. Glucose was determined to be present in this spot; other sugars were not detected.

The characteristics of the novel isolates are shown in Table 2 (details are also given in the species description). Some phenotypic characteristics of the novel isolates were

Table 2. Differential characteristics of Lactobacillus sucicola sp. nov. and closely related lactobacilli

Strains: 1 , NRIC $0735 ; 2$, NRIC $0736^{\mathrm{T}}$; 3, NRIC 0737; 4, L. mali (unless indicated, data from Kaneuchi et al., 1988); 5, L. satsumensis (Endo \& Okada, 2005). +, Positive; -, negative; v, variable.

\begin{tabular}{|lccccc|}
\hline Characteristic & $\mathbf{1}$ & $\mathbf{2}$ & $\mathbf{3}$ & $\mathbf{4}$ & $\mathbf{5}$ \\
\hline Motility & + & + & + & + & + \\
Catalase production & - & - & - & $\mathrm{V}$ & - \\
Acid from: & & & & & \\
$\quad$ Cellobiose & - & - & - & $\mathrm{V}$ & - \\
$\quad$ D-Galactose & + & + & + & - & + \\
$\quad$ Maltose & - & + & + & - & - \\
$\quad$ Melibiose & + & + & + & - & - \\
$\quad$ Raffinose & - & + & - & - \\
Growth in MRS broth containing $5 \% \mathrm{NaCl}$ & - & - & - & $\mathrm{V}$ & + \\
& & & & & \\
\hline
\end{tabular}

different from those of L. satsumensis (Endo \& Okada, 2005) and L. mali (Carr \& Davies, 1970; Nonomura, 1983; Kaneuchi et al., 1988). Some phenotypic characteristics of the novel isolates were similar to those of L. satsumensis and L. mali, for example the novel strains were motile with peritrichous flagella (See Supplementary Fig. S1 in IJSEM Online).

On the basis of the results of this study, the three new isolates are regarded as representing a novel species in the genus Lactobacillus, for which the name Lactobacillus sucicola sp. nov. is proposed.

\section{Description of Lactobacillus sucicola sp. nov.}

Lactobacillus sucicola [su'ci.co'la. L. n. sucus sap; L. suff. - cola (from L. n. incola) inhabitant, dweller; N.L. n. sucicola a sap-dweller].

Cells are Gram-positive rods measuring 1.0 $\times 2.0-3.0 \mu \mathrm{m}$. Cells occur singly or in pairs and are motile by means of peritrichous flagella. Facultatively anaerobic and catalasenegative. Colonies are white, smooth and $2 \mathrm{~mm}$ diameter on MRS agar plates incubated at $30{ }^{\circ} \mathrm{C}$ for $3-4$ days. Homofermentative. No gas is produced from D-glucose. LLactic acid is produced from glucose as the main end product. Acid is produced from D-glucose, D-fructose, D-galactose, D-mannose, melibiose, sucrose, D-salicin, trehalose, D-mannitol and sorbitol, but not from Larabinose, D-ribose, D-xylose, gluconate, rhamnose, cellobiose, lactose, melezitose or starch. Acid production from maltose and raffinose is variable between strains. Dextran is produced from sucrose. Cells grow at 15 and $45{ }^{\circ} \mathrm{C}$, but not at 10 or $50{ }^{\circ} \mathrm{C}$. Growth is not observed in GYP broth containing $5 \%(\mathrm{w} / \mathrm{v}) \mathrm{NaCl}$. The cell-wall peptidoglycan contains meso-diaminopimelic acid as the diagnostic diamino acid. The DNA G $+\mathrm{C}$ content ranges from 37 to $38 \mathrm{~mol} \%$ (type strain, $38 \mathrm{~mol} \%$ ).

The type strain, NRIC $0736^{\mathrm{T}} \quad\left(=\mathrm{JCM} \quad 15457^{\mathrm{T}}=\mathrm{DSM}\right.$ $21376^{\mathrm{T}}$ ), was isolated from the sap of an oak (Quercus sp.) from Awashima Island, Kagawa Prefecture, Japan. Additional strains were also isolated from the oak sap.

\section{Acknowledgements}

We thank K. Komagata for his valuable advice. We are also grateful to M. Ishikawa, Department of Fermentation Science, Tokyo University 
of Agriculture, for his valuable advice and M. Kanazawa, NODAI Culture Collection Center, Faculty of Applied Bioscience, Tokyo University of Agriculture, for her technical assistance.

\section{References}

Brosius, J., Dull, T. J., Sleeter, D. D. \& Noller, H. F. (1981). Gene organization and primary structure of a ribosomal RNA operon from Escherichia coli. J Mol Biol 148, 107-127.

Carr, J. G. \& Davies, A. (1970). Homofermentative lactobacilli of cider including Lactobacillus mali nov. spec. J Appl Bacteriol 33, 768-774.

Collins, M. D., Rodrigues, U. M., Ash, C., Aguirre, M., Farrow, J. A. E., Martinez-Murcia, A., Philips, B. A., Williams, A. M. \& Wallbanks, S. (1991). Phylogenetic analysis of the genus Lactobacillus and related lactic acid bacteria as determined by reverse transcriptase sequencing of 16S rRNA. FEMS Microbiol Lett 77, 5-12.

Endo, A. \& Okada, S. (2005). Lactobacillus satsumensis sp. nov., isolated from mashes of shochu, a traditional Japanese distilled spirit made from fermented rice and other starchy materials. Int J Syst Evol Microbiol 55, 83-85.

Ezaki, T., Yamamoto, N., Ninomiya, K., Suzuki, S. \& Yabuuchi, E. (1983). Transfer of Peptococcus indolicus, Peptococcus asaccharolyticus, Peptococcus prevotii and Peptococcus magnus to the genus Peptostreptococcus and proposal of Peptostreptococcus tetradius sp. nov. Int J Syst Bacteriol 33, 683-698.

Ezaki, T., Hashimoto, Y. \& Yabuuchi, E. (1989). Fluorometric deoxyribonucleic acid-deoxyribonucleic acid hybridization in microdilution wells as an alternative to membrane filter hybridization in which radioisotopes are used to determine genetic relatedness among bacterial strains. Int J Syst Bacteriol 39, 224-229.

Felsenstein, J. (1985). Confidence limits on phylogenies: an approach using the bootstrap. Evolution 39, 783-791.

Hucker, G. J. \& Conn, H. J. (1923). Method of Gram staining N Y State Agric Exp Stn Tech Bull 93, 3-37.
Kaneuchi, C., Seki, M. \& Komagata, K. (1988). Taxonomic study of Lactobacillus mali Carr and Davis 1970 and related strains: validation of Lactobacillus mali Carr and Davis 1970 over Lactobacillus yamanashiensis Nonomura 1983. Int J Syst Bacteriol 38, 269-272.

Kimura, M. (1980). A simple method for estimating evolutionary rates of base substitutions through comparative studies of nucleotide sequences. J Mol Evol 16, 111-120.

Komagata, K. \& Suzuki, K. (1987). Lipid and cell-wall analysis in bacterial systematics. Methods Microbiol 19, 161-207.

Manome, A., Okada, S., Uchimura, T. \& Komagata, K. (1998). The ratio of $\mathrm{L}$-form to $\mathrm{D}$-form of lactic acid as a criteria for the identification of lactic acid bacteria. J Gen Appl Microbiol 44, 371-374.

Marmur, J. (1961). A procedure for the isolation of deoxyribonucleic acid from microorganisms. J Mol Biol 3, 208-218.

Nonomura, H. (1983). Lactobacillus yamanashiensis subsp. yamanashiensis and Lactobacillus yamanashiensis subsp. mali sp. and subsp. nov., nom. rev. Int J Syst Bacteriol 33, 406-407.

Okada, S., Hosoi, Y., Takahashi, M. \& Kozaki, M. (1991). A rapid method for the determination of the fermentation types, homo- and hetero-fermentation, of lactic acid bacteria. Bull JFCC 7, 6-10 (in Japanese).

Saitou, N. \& Nei, M. (1987). The neighbor-joining method: a new method for reconstructing phylogenetic trees. Mol Biol Evol 4, 406-425.

Tamaoka, J. \& Komagata, K. (1984). Determination of DNA base composition by reversed-phase high-performance liquid chromatography. FEMS Microbiol Lett 25, 125-128.

Thompson, J. D., Gibson, T. J., Plewniak, F., Jeanmougin, F. \& Higgins, D. G. (1997). The CLUSTAL_X Windows interface: flexible strategies for multiple sequence alignment aided by quality analysis tools. Nucleic Acids Res 25, 4876-4882.

Toda, T. (1928). Flagellar staining. Nihon Ijishinpo 283, 113 (in Japanese).

Zhu, H., Qu, F. \& Zhu, L. H. (1993). Isolation of genomic DNAs from plants, fungi, and bacteria using benzyl chloride. Nucleic Acids Res 21, 5279-5280. 